\title{
CONTRAMAJORITARISMO DIALÓGICO-ARGUMENTATIVO E LEGITIMAÇÃO DAS EXPECTATIVAS INSTITUCIONAIS: O PAPEL ESTABILIZADOR DAS CORTES NAS SOCIEDADES COMPLEXAS
}

\author{
Luis Claudio Martins de Araujo ${ }^{1}$ \\ Guilherme Braga Peña de Moraes ${ }^{2}$
}

\begin{abstract}
Resumo
Com a globalização e o crescimento da chamada sociedade internacional, interdependente e interpenetrante, que interage cada dia de forma mais profunda, o exercício do poder jurisdicional em sistemas jurídicos autônomos, tem se expandido em todo o mundo, consolidando a ideia de que cabe ao Poder Judiciário dizer a última palavra em questões constitucionais e de direitos humanos. Neste sentido, diante desta ampliação do papel do Poder Judiciário em diversos sistemas jurídicos, mais do que nunca, a decisão sobre questões morais e políticas complexas, nas quais existem divergências profundas na sociedade sobre o conteúdo dos direitos e a forma de interpretá-los, é reservada a juízes não eleitos democraticamente. Neste sentido, pode-se estatuir que, o sistema de supremacia judicial, acaba por trazer impactos efetivos à questão democrática, e, portanto, para que seja devidamente legitimado, deve ser desenvolvido de forma coerente com outras instituições e Poderes Constituídos. Desta feita, em sociedades complexas o aparecimento de modelos dialógico-argumentativos, acaba por ampliar as perspectivas do debate legitimatório das Cortes, buscando o devido equilíbrio institucional em um sistema democrático, ao apresentar uma adequada e eficaz proteção de direitos, através de uma redistribuição de poderes entre os tribunais e as demais instituições, garantindo o diálogo entre os diversos atores nos sistemas jurídico e político, permitindo maior ganho para a questão legitimatória e democrática.
\end{abstract}

Palavras-chave: jurisdição constitucional, direitos humanos, análise dialógico-argumentativa, cortes constitucionais.

\footnotetext{
${ }^{1}$ Pós-Doutorando em Direito pela Universidade Federal do Rio de Janeiro (UFRJ). Academic Visitor pela University of Oxford (Oxford). Visiting Fellow pelo Lauterpacht Centre for International Law da University of Cambridge (Lauterpacht Centre). Visiting Researcher pela Fordham University School of Law (Fordham). Mestre em Direito pela Universidade Federal do Rio de Janeiro (UFRJ). Professor da graduação da Universidade Federal do Rio de Janeiro (UFRJ). Professor da graduação e pósgraduação da Faculdade de Ciências Sociais Aplicadas do Instituto Brasileiro de Mercado de Capitais (IBMEC). Professor convidado da pós-graduação da Fundação Getúlio Vargas (FGV), Escola da Magistratura do Estado do Rio de Janeiro (EMERJ), da Escola da Advocacia-Geral da União (EAGU), da Escola de Administração Judiciária do Tribunal de Justiça do Estado do Rio de Janeiro (ESAJ) e da Universidade Cândido Mendes (UCAM). Membro da Advocacia-Geral da União (AGU) de categoria especial. Vice-Diretor da Escola da Advocacia-Geral da União (EAGU).E-mail: luis.araujo@agu.gov.br

${ }^{2}$ Membro do Ministério Público do Estado do Rio de Janeiro. Professor Adjunto da Faculdade de Direito e Professor Permanente do Programa de Pós-Graduação em Direito Constitucional da Universidade Federal Fluminense (UFF). Mestre em Direito Constitucional pela Pontifícia Universidade Católica do Rio de Janeiro (PUC/RJ). Doutor em Direito Constitucional pela Pontifícia Universidade Católica de São Paulo (PUC/SP). Pós-Doutor em Direito Constitucional pela Fordham School of Law Jesuit University of New York (FU/NY).E-mail: gmoraes@mp.rj.gov.br
} 


\section{INTRODUÇÃO}

O presente artigo será estruturado a partir da formulação de um modelo de análise dialógicoargumentativo, que permita gerar uma contribuição para a justificação de um novo paradigma de legitimação das cortes no exercício da jurisdição constitucional e dos direitos humanos ${ }^{3,4}$, com a estabilização das expectativas institucionais nas sociedades complexas. Neste sentido, ao se analisar a atuação das cortes no desempenho da jurisdição constitucional e dos direitos humanos, é imperioso que se adotem critérios, construídos sob a égide de parâmetros dialógico-argumentativos, afirmando a necessidade de se construir parâmetros e diretrizes de uma agenda cooperativa para a legitimação da jurisdição constitucional e de direitos humanos nas sociedades complexas.

Neste sentido, cabe destacar a necessária construção de argumentos que permitam justificar um modelo de análise dialógico-argumentativo, sob a égide de mecanismos capazes de possibilitar um novo paradigma de legitimação da jurisdição constitucional e dos direitos humanos, permitindo uma leitura compreensível da realidade, no que tange ao comportamento normativo e deliberativo e às suas funções dialógicas.

Na verdade, muito se vem discutindo, atualmente, sobre a legitimidade da atuação entre os Poderes de Estado e das instituições supranacionais, sobretudo na consolidação do papel da jurisdição constitucional e de direitos humanos na estabilização social, sob a égide de parâmetros democráticos e pautas de agenda cooperativa e dialógica. Assim, o estudo da legitimação da jurisdição constitucional e dos direitos humanos, demanda a formulação de um modelo de análise dialógico-argumentativo, que permita a justificação de um novo paradigma de interpretação, decisão, atuação e cooperação, em que os deveres institucionais sejam determinados, partindo-se dos fundamentos de razão pública, e, mais concretamente, que o exercício dessas atividades passe por um procedimento que possa ser concebido como legítimo pela sociedade.

Desta forma, a ideia será trabalhar a incorporação de novos pontos de vista no debate jurisdicional, a partir de uma reflexão crítica, em que a ideia de previsibilidade e equidade na atuação das cortes, passe a ser repensada sob o prisma dialógico-argumentativo, trazendo uma nova perspectiva de análise da legitimação da

\footnotetext{
${ }^{3}$ A jurisdição de tutela dos direitos fundamentais e direitos humanos, pode se desenvolver através da jurisdição constitucional, que é o poder das Cortes constitucionais de interpretar a legislação e invalidar os atos incompatíveis com a Constituição e com os direitos fundamentais, e, mediante a jurisdição de direitos humanos, produzida pelas Cortes internacionais, supranacionais ou regionais, ao interpretar o Direito Internacional e comunitário, em questões de Direitos Humanos. Ademais, a jurisdição constitucional e a jurisdição de Direitos Humanos, segundo a premissa metodológica aqui desenvolvida, podem ser exercidas por instituições que não necessariamente, ao menos no sentido estrito do termo, podem ser qualificadas como órgãos judiciais, desde que esta atividade não seja efetuada, exclusivamente, pelo Poder Executivo ou Poder Legislativo como é o caso do Conseil d'Etat francês, da Comissão Europeia de Direitos Humanos e da Comissão Interamericana de Direitos Humanos.

${ }^{4}$ Utilizaremos os vocábulos Tribunal Constitucional e Corte Constitucional como sinônimos. Da mesma maneira, utilizaremos indistintamente as expressões jurisdição constitucional, judicial review e controle de constitucionalidade.
} 
jurisdição constitucional e dos direitos humanos, com a integração estável das instituições, no plano cooperativo e dialógico, buscando alcançar uma deliberação que atenda aos interesses e valores da coletividade, resultados de uma prática discursiva racional.

Neste sentido, para o desenvolvimento deste artigo, será preciso recorrer a algumas referências teóricas fundamentais, para estabelecer uma teoria que compreenda mecanismos e instrumentos capazes de aperfeiçoar o exercício da jurisdição constitucional e dos direitos humanos, pela via sistêmico-dialógica, estabelecendo uma dinâmica segura na adoção de princípios apriorísticos devidamente compartilhados.

Assim, uma reflexão sobre tais princípios deve estar diretamente relacionada à ideia de razão pública, defendida por Rawls ${ }^{5}$ como uma cultura democrática, e, desenvolvida por Habermas ${ }^{6}$ como uma instrumentalização racional da comunicação e interação entre seus atores discursivos. Da mesma forma, será necessário tomar como referencial, a observação de Jeremy Waldron ${ }^{7}$, no sentido de que há a necessidade de criação de uma rede de reciprocidade arquitetada a partir de um consenso por meio de um procedimento democrático compatível com as diferentes concepções de justiça de uma sociedade complexa ${ }^{8}$. Assim, irá se procurar contextualizar esse fenômeno, com base nas lições de Anne-Marie Slaughter', a partir da intensificação de um diálogo pluralista e participativo, para determinar a legitimação da jurisdição constitucional e dos direitos humanos nas sociedades complexas.

\section{CONTRAMAJORITARISMO DIALÓGICO-ARGUMENTATIVO E LEGITIMAÇÃO DAS EXPECTATIVAS INSTITUCIONAIS}

Ao se analisar o momento mais recente da história, observa-se que o sistema de proteção de direitos, ancorado em um modelo de jurisdição constitucional e de direitos humanos, passa a ser estudado a partir do crescente processo de judicialização da moral, da política ${ }^{10}$ e das relações sociais ${ }^{11}$, corolário da expansão e do

\footnotetext{
${ }^{5}$ RAWLS, John. Justiça e democracia. São Paulo: Martins Fontes, 2000.

${ }^{6}$ HABERMAS, Jürgen. Direito e democracia: entre facticidade e validade. Tradução Flávio Beno Siebeneichler. 2. ed. Rio de Janeiro: Tempo Brasileiro, 2003, v. 1.

${ }^{7}$ WALDRON, Jeremy. Teaching cosmopolitan right. In: MCDONOUGH, Kevin; FEINBERG, Walter. (Eds.) Education and citizenship in liberal-democratic societies: cosmopolitan values and cultural identities. Oxford: Oxford University Press, 2003. p. 25-35.

${ }^{8}$ Idem. Minority cultures and the cosmopolitan alternative. University of Michigan Journal of Law Reform, v. 25, p.751-778, 19911992.

${ }^{9}$ SLAUGHTER, Anne-Marie. A global community of courts. Harvard International Law Journal, v. 44, p. 191, 2003.

${ }^{10}$ De acordo com C. Neal Tate e Torbjorn Vallinder, a judicialização da política pode significar a expansão da jurisdição das cortes ou dos juízes no âmbito político e/ou administrativo, ou, a propagação dos métodos judiciais de tomada de decisão, para além da jurisdição apropriada. TATE, C. Neal; VALLINDER, Torbjorn. The global expansion of judicial power. New York University, 1997, p. 13.

${ }^{11}$ Lembra-se que o conceito de judicialização, não se confunde o conceito de ativismo judicial. Luís Roberto Barroso, atento à recorrente distorção entre os conceitos, esclarece a distinção existente: "A judicialização e o ativismo judicial são primos. Vêm, portanto, da mesma família, frequentam os mesmos lugares, mas não têm as mesmas origens. A judicialização, no contexto
} 
fortalecimento do papel das cortes, pautado, especialmente, em técnicas de controle judicial, dentro de processos de disseminação dos métodos judiciais para arenas políticas.

Neste sentido, com a busca crescente pela concretização de direitos e garantias, cada vez mais, as questões sociais e morais passam a ser absorvidas pelo Direito, e, então, tendem a se resolver através da aplicação de procedimentos inspirados na forma judicial ${ }^{12}$, com a evolução do papel das cortes no controle das deliberações normativas.

Simultaneamente, este processo de avanço da jurisdição de direitos fundamentais e direitos humanos em escala global, carreia a percepção de que a solução judicial de problemas complexos ${ }^{13}$ se apresenta a mais adequada, uma vez que a permanente desconfiança e o questionamento da legitimidade em relação a atuação estatal, acarreta o deslocamento da autoridade do sistema representativo para os tribunais, como cultores últimos dos diretos, com respostas para todos os problemas jurídicos e políticos.

Um dos grandes problemas desta concepção, contudo, se dá pelo fato de que na jurisdição constitucional e de direitos humanos, a decisão sobre questões morais e políticas complexas, nas quais existem divergências profundas na sociedade sobre o conteúdo dos direitos e a forma de interpretá-los, é reservada a juízes não eleitos democraticamente ${ }^{14}$.

Desta forma, a prática argumentativa da jurisdição constitucional e de direitos humanos deve assumir a compreensão dos critérios democráticos da comunidade ${ }^{15}$, a partir do pressuposto de que a corte não está dispensada de fundamentar suas decisões ${ }^{16}$, e, assim, demonstrar, de forma racional, que a legitimidade de uma

brasileiro, é um fato, uma circunstância que decorre do modelo constitucional que se adotou, e não um exercício deliberado da vontade política. (...) Já o ativismo judicial é uma atitude, a escolha de um modo específico e proativo de interpretar a Constituição, expandindo o seu sentido e alcance. Normalmente ele se instala em situações de retração do Poder Legislativo, de um certo descolamento entre a classe política e a sociedade civil, impedindo que as demandas sociais sejam atendidas de maneira efetiva." BARROSO, Luís Roberto. Judicialização, ativismo e legitimidade democrática. Disponível em: <http://www.oab.org.br/ editora/revista/users/revista/1235066670174218181901.pdf>. Acesso em: 13 jan. 2015.

${ }^{12}$ HIRSCHL, Ran. The new constitucionalism and the judicialization of pure politics worldwide. Fordham Law Review, v. 75, n. 2, p. 721-754, 2006.

${ }^{13}$ Segundo Rodrigo Brandão, em situações de grande complexidade, a corte pode se deparar com falta de informações, circunstâncias mutáveis e desacordo moral razoável. Assim, uma eventual postura maximalista em face de questões altamente complexas, aumenta a possibilidade de erro e a dificuldade da sua correção, sobretudo se adotada pela Suprema Corte em regimes de supremacia judicial, nos quais a interpretação constitucional só pode ser revertida por nova decisão da Suprema Corte ou por Emenda Constitucional. Mesmo uma decisão boa, porém precipitada, pode gerar efeitos ruins à democracia, pois a colocação de uma visão sobre questão controvertida fora do alcance de maiorias legislativas ordinárias, produz tendencial polarização no debate político, já que os perdedores não se sentirão reconhecidos pelo projeto constitucional e tenderão a radicalizar os seus discursos e práticas. BRANDÃO, Rodrigo. Supremacia judicial versus diálogos constitucionais: a quem cabe a última palavra sobre o sentido da Constituição? Rio de Janeiro: Lumen Juris, 2012, p. 184-185.

${ }^{14}$ Este déficit de legitimidade democrática de juízes não eleitos, quanto à invalidação de decisões tomada pelos representantes eleitos do povo, foi definido por Alexander Bickel como dificuldade contramajoritária. Para tanto vide: BICKEL, Alexander. The least dangerous branch: the Supreme Court at the bar of politics. 2. ed. New Haven: Yale University Press, 1986.

${ }^{15}$ NINO, Carlos Santiago. La constituición de la democracia deliberativa. Barcelona: Gedisa, 1997, p. 21 e ss.

${ }^{16}$ NINO, Carlos Santiago. Ética y derechos humanos. Buenos Aires: Astrea, 1989, p. 32 e ss. 
decisão majoritária ${ }^{17}$ não se encontra em descompasso com os direitos fundamentais, direitos humanos ou direitos de minorias ${ }^{18,19}$.

É bem verdade, também, que o isolamento relativo de juízes da influência política tende à imparcialidade, ou seja, através da jurisdição constitucional e de direitos humanos, um dos papéis institucionais mais importantes das cortes é o de proteger os direitos das minorias diante dos abusos das maiorias, visto que o insulamento dos juízes confere uma vantagem institucional comparativa para desempenhar essa relevante função contramajoritária $^{20,21}$, que em certa medida, funciona com o papel de estabilizadora institucional, arbitrando conflitos, e resguardando os valores fundamentais e os procedimentos democráticos ${ }^{22}$.

Contudo, apesar desse importante papel exercido pelos tribunais, a história acaba por demonstrar que, existiram cenários em que a atuação das cortes se deu contra os direitos das minorias, como se observa, exemplificativamente, de alguns julgados da Suprema Corte norte-americana, como Dred Scott v. Sanford de $1857^{23}$ — ao se entender que os negros não eram considerados cidadãos norte-americanos e não pleitear direitos previstos na Constituição —, Hammer v. Dagenhart de $1918^{24}$ — ao decidir que uma lei de 1916 que proibia o

\footnotetext{
${ }^{17}$ GARGARELLA, Roberto. La justicia frente al gobierno (sobre el carácter contramayoritario del poder judicial). Barcelona: Ariel, 1996, p. 33 ess.

${ }^{18}$ Segundo Fioravanti "El parlamento era soberano porque no aparecía como una autoridad derivada, legitimada por el principio democrático de la soberanía popular. (..) Por este mismo motivo la ley del parlamento no puede ser derogada, modificada o alterada por otra autoridad: si eso fuese posible, se abriría evidentemente el problema de individuar, por esta vía, un sujeto superior al parlamento, autor de una ley constitucional superior a la del parlamento. En el fondo, si los mismos jueces americanos pensaban que podían y debían no aplicar las leyes que se pensaban que estaban en contraste con la constitución, era porque en aquel sistema había que tutelar en primer lugar la supremacía de la ley fundamental, es decir, de la voluntad del pueblo soberano, de un sujeto originario superior al mismo legislador. En pocas palabras, poner en discusión la soberanía del parlamento, incluso mediante el control de constitucionalidad, significaba antes o después reabrir la cuestión de la soberanía popular, del poder constituyente, de la democracia". FIORAVANTI, Maurizio. Constitución: De la antiguedad a nuestros dias. Tradução Manuel Martinez Neira. Madrid: Trotta, 2001, p. 146.

${ }^{19}$ ZURN, Christopher F. Deliberative Democracy and the Institutions of Judicial Review. New York: Cambridge University Press. 2007, p. 89 ess.

${ }^{20}$ NEGRETTO, Gabriel. Diseño constitucional y separación de poderes en América Latina. Revista Mexicana de Sociología, v. 65, n. 1,2003, p. 41-76.

${ }^{21}$ KERSCH, Ken I. The New Legal Transnalionalism, the Globalized Judiciary and the Rule of Law. Washington University Global Studies Law Review, n. 4, 2005, p. 345.

${ }^{22}$ BARROSO, Luís Roberto. Neoconstitucionalismo e constitucionalização do direito. O triunfo tardio do direito constitucional no Brasil. In: SAMPAIO, José Adércio Leite (Org.). Constituição e crise política. Belo Horizonte: Del Rey, 2006, p. 97-148.

${ }^{23}$ A decisão proferida pela Suprema Corte dos Estados Unidos em Dred Scott v. Sanford de 1857, foi especialmente lesiva aos afrodescendentes. No caso, a Suprema Corte julgou improcedente demanda de escravo que postulara a sua libertação, entendendo que os negros não eram considerados cidadãos norte-americanos, pelo que não poderiam postular a salvaguarda de direitos previstos na Constituição. Dred Scott v. Sanford foi superado apenas pela décima terceira emenda, que extinguiu a escravidão, em uma rara hipótese no cenário norte-americano de superação pelo Poder Legislativo de decisão tomada pela Suprema Corte. BRANDÃO, Rodrigo. Supremacia judicial versus diálogos constitucionais: a quem cabe a última palavra sobre o sentido da Constituição? Rio de Janeiro: Lumen Juris, 2012, p. 12, 245 e 281.

${ }^{24} \mathrm{Da}$ mesma forma, a Suprema Corte tomou inúmeras decisões contrárias à tentativa de extinguir o trabalho infantil nos Estados Unidos. Em Hammer v. Dagenhart, a Suprema Corte decidiu que uma lei de 1916, que proibia o trabalho infantil seria inconstitucional, uma vez que a lei estaria fora dos limites do poder de comércio interestadual, e também violaria os direitos dos Estados sob a Décima Emenda. Posteriormente, em Bailey v. Drexel Furniture Co., a Suprema Corte entendeu que também seria inconstitucional, cobrar tributos sobre bens produzidos, que se valessem de trabalho infantil, por violação da Décima Emenda.
} 
trabalho infantil seria inconstitucional —, Hirabayashi v. United States de $1943^{25}$ - ao entender que o confinamento de grupos minoritários seria constitucional, nos casos em que os Estados Unidos estivesse em guerra - Korematsu v. United States de $1944^{26}$ — ao entender pela constitucionalidade da permanência de nipo-americanos em campos de confinamento durante a Segunda Guerra Mundial.

Da mesma forma, a Suprema Corte norte-americana, tomou em diversas outras decisões restritivas sobre direitos fundamentais promovidos na arena política ${ }^{27,28}$, como em Lochner v. New York de $1905^{29}$, ao decidir pela

Apenas em 1941, em United States v. Darby Lumber Co., a Suprema Corte entendeu pela constitucionalidade da Fair Labor Standards Act de 1938, que proibia o trabalho infantil em inúmeras situações. GRIFFIN, Stephen. American constitutionalism: from the theory to the politics. Princeton University Press, 1999, p. 88-89.

${ }^{25}$ No caso, o Presidente Franklin D. Roosevelt em 1942, durante a 20 Guerra Mundial, emitiu a Executive Order 9066, que permitia a limitação e exclusão de certas pessoas de certas áreas. Assim, foi imposto o toque de recolher contra estrangeiros de ascendência japonesa, e sobre nipo-americanos. Mais tarde, foram criadas áreas de confinamento contra japoneses e nipo-americanos. Gordon Kiyoshi Hirabayashi, foi acusado e condenado por violar a ordem de toque de recolher, tendo a Suprema Corte norte-americana confirmado a condenação, o que culminou com o envio do réu para campo de confinamento. Em 1986 e 1987, as condenações de Hirabayashi foram overturned pela United States District Court in Seattle e pela Federal Appeals Court, porque as evidências para condenação seriam falsas. CANON, Bradley C. Defining the Dimensions of Judicial Activism. Judicature, v. 66, n. 6, 1983, p. $236-$ 247.

${ }^{26}$ Em Korematsu v. United States, da mesma forma, a Suprema Corte norte-americana entendeu pela constitucionalidade da Executive Order 9066, e pela permanência de nipo-americanos em campos de confinamento durante a Segunda Guerra Mundial. No caso, a Suprema Corte considerou a necessidade de proteger o país contra possíveis atos de espionagem perpetrados por japoneses e americanos descendentes de japoneses, com limitação de direitos individuais. A decisão em Korematsu v. United States, foi overturned em 1983, pela United States District Court for the Northern District of California, pois o governo federal teria apresentado informações falsas à Suprema Corte. CANON, loc. cit.

${ }^{27}$ A discussão do papel do tribunal no sistema político, possui inúmeros precedentes extremamente relevantes, como na crise do Court-Packing de 1937, em que o Presidente Franklin D. Roosevelt, tentou forçar a nomeação de novos juízes para a Suprema Corte, após o Tribunal ter decidido oito casos importantes contra o New Deal (Panama Refining Co. v. Ryan de 1935, A.L.A. Schechter Poultry Corp. v. United States de 1935, Louisville Joint Stock Land Bank v. Radford de 1935, Railroad Retirement Board v. Alton Railroad Co. de 1935, United States v. Butler de 1936, Carter v. Carter Coal Company de 1936, Ashton v. Cameron County Water Improvement District de 1936, Morehead v. New York ex rel. Tipaldo de 1936). BRANDÃO, Rodrigo. Supremacia judicial versus diálogos constitucionais: a quem cabe a última palavra sobre o sentido da Constituição? Rio de Janeiro: Lumen Juris, 2012, p. 228-230.

${ }^{28}$ Em certa medida, a interferência da Corte em questões políticas, pode ser observada no recente julgamento do Supremo Tribunal Federal no Mandado de Segurança 34530, que determinou a suspensão da tramitação do projeto de lei de iniciativa popular de combate à corrupção (PL 4.850/2016), vedando o uso de emendas e substitutivos que desfigurassem a proposta original, bem como a prática de apropriação da autoria do projeto por um ou mais deputados, um vez que, no caso concreto, uma emenda de Plenário incluiu na proposta, tópico relativo a crimes de abuso de autoridade por parte de magistrados e membros do Ministério Público. Mandado de Segurança $34530 . \quad$ Disponível em: <http://www.stf.jus.br/arquivo/cms/noticiaNoticiaStf/anexo/MS34530.pdf>. Acesso em: 4 dez. 2016.

${ }^{29}$ A Suprema Corte norte-americana, também tomou inúmeras decisões contrárias aos interesses daqueles que buscavam as reformas sociais e econômicas. Este período foi chamado de "a era Lochner", após o julgamento de Lochner v. New York de 1905, momento histórico definido por decisões judiciais de invalidação das leis sociais em geral, em detrimento de valores que compunham o ideal liberal. No caso, o Estado de Nova York editou em 1895, o Bakeshop act, lei que regulava as condições sanitárias e de trabalho em padarias e que possuía, dentre seus dispositivos, uma limitação à carga horária dos padeiros em dez horas diárias ou sessenta horas semanais. $\mathrm{O}$ desrespeito à mencionada regra, acarretava a pena de multa ao responsável pelo estabelecimento. Joseph Lochner era dono de uma padaria, situada em território dentro da jurisdição de Nova York. Indignado com o recebimento da segunda multa, em virtude do desrespeito à restrição legal do período de trabalho de seus funcionários, ele levou a controvérsia até os tribunais. Em seu ponto de vista, a lei do Estado de Nova York violava a liberdade de contratar, direito constitucionalmente albergado, sob a cláusula do devido processo legal em seu aspecto substancial. Em 1905, a Suprema Corte, então, decidiu, diante de apertada votação (cinco votos a quatro), declarar a inconstitucionalidade da referida legislação, alegando 
inconstitucionalidade do Bakeshop act, que limitava a carga horária dos padeiros, em virtude da liberdade de contratar, direito constitucionalmente albergado, sob a cláusula do devido processo legal em seu aspecto substancial.

O Conseil Constitutionnel francês na Décision 2010-613 DC de 2010 30,31 e o Tribunal Constitucional da Bélgica no Arrêt 145/2012 de 2012 ${ }^{32}$, também atuaram de maneira similar, ao considerar a proibição do ocultamento do rosto em locais públicos ("leis da burca"), compatível com o direito à liberdade de pensamento, de expressão, consciência, religião e do direito à vida privada.

Esta mesma visão pode ser observada na temática dos direitos sociais, como no Recurso Extraordinário 693456 ${ }^{33}$, em que o Supremo Tribunal Federal entendeu que o Poder Público pode descontar os dias parados por greve de servidor em folha de pagamento, e, nos Recursos Extraordinários 661256, 381367 e 827833³4, ao considerar inviável o recálculo do valor da aposentadoria por meio da chamada desaposentação. ser desarrazoada, desnecessária e arbitrária, a limitação que a mesma impunha à liberdade de contratar. O período Lochner foi
superado pelo julgamento de West Coast Hotel Co. v. Parrish em 1937. BRANDÃO, op. cit., p. 228-229.
${ }^{30} \mathrm{Na}$ Décision 2010-613 DC de 2010, o Conselho Constitucional, exercendo seu controle prévio de constitucionalidade,
entendeu pela constitucionalidade da Lei Francesa 2010-1192 (também chamada de "lei da burca"), que trata da proibição do
ocultamento do rosto em locais públicos, visto que, incompatível com os valores da república francesa, da liberdade, igualdade e
fraternidade, erepresentaria uma clara violação aos princípios da laicidade edo vivre ensemble, e, portanto, a proibição se justificaria
como garantia à segurança pública, apresentando apenas a ressalva de que a vedação prevista na Lei 2010-1192, não poderia se
estender aos locais de culto abertos ao público. Décision 2010-613 DC. Disponível em: <http://www.conseil-
constitutionnel.fr/conseil-constitutionnel/francais/les-decisions/acces-pardate/decisions-depuis-1959/2010/2010-613-

dc/decision-n-2010-613-dc-du-07-octobre2010.49711.html>. Acesso em: 6 fev. 2016.

${ }^{31}$ A Lei 2010-1192, não é a primeira lei francesa a impor restriçōes ao uso de vestimentas que encobrem a face, uma vez que a discussão sobre a restrição da indumentária islâmica, já estava presente na agenda da política francesa ao menos uma década antes, quanto ao uso do hijab nas escolas públicas, quando o Presidente Jacques Chirac decidiu criar uma comissão específica (comissão Stasi), para examinar o princípio da laicidade, o que levou, ao final, à aprovação da Lei 2004-228 de 15 de março de 2004, comumente chamada de "lei do véu". Décision 2010-613 DC. Disponível em: <http://www.conseil-constitutionnel.fr/conseilconstitutionnel/ francais/les-decisions/acces-pardate/decisions-depuis-1959/2010/2010-613-dc/decision-n-2010-613-dc-du07-octobre2010.49711.html>. Acesso em: 6 fev. 2016.

${ }^{32}$ No Arrêt 145/2012 de 6 de dezembro de 2012, o Tribunal Constitucional da Bélgica, considerou compatível com o direito à liberdade de pensamento, de expressão, consciência, religião e do direito à vida privada, a Lei belga de 13 de julho de 2011 , que trata da proibição de esconder o rosto em público, desde que a proibição não se estenda aos locais de culto abertos ao público. Arrêt 145/2012. Disponível em: <http://www.const-court.be/public/f/2012/2012-145f.pdf>. Acesso em: 6 fev. 2016.

${ }^{33}$ Em decisão anterior, no julgamento dos Mandados de Injunção 670 e 712, o STF havia decidido que, até a edição da lei regulamentadora do direito de greve, previsto no art. 37, VII da Constituição, as Leis 7701/1988 e 7783/1989 poderiam ser aplicadas provisoriamente para possibilitar o exerćício do direito de greve pelos servidores públicos. Ou seja, a Corte entendeu que, durante a ausência de norma regulamentadora, se aplicaria, aos servidores públicos, as normas que regem o direito de greve dos trabalhadores submetidos ao regime celetista, e, que o movimento grevista deflagrado por servidores públicos, ainda que na ausência de norma regulamentadora, não se configura um ato ilícito, mesmo porque há norma constitucional definidora de um direito fundamental. Assim, diante da omissão legislativa, o Supremo Tribunal Federal vinha garantindo a eficácia mínima do direito constitucional de greve à categoria dos servidores públicos. Contudo, no Recurso Extraordinário 693456, a Corte entendeu que, os salários dos dias de paralisação não deverão ser pagos, salvo no caso em que a greve tenha sido provocada justamente por atraso no pagamento aos servidores públicos civis, ou por outras situações excepcionais que justifiquem o afastamento da premissa da suspensão do contrato de trabalho. Recurso Extraordinário 693456. Disponível em: <http://www.stf.jus.br/portal/cms/verNoticiaDetalhe.asp?idConteudo=328294>. Acesso em: 4 dez. 2016.

${ }^{34}$ Segundo o entendimento do Supremo, somente por meio de lei é possível fixar critérios para que os benefícios sejam recalculados com base em novas contribuições decorrentes da permanência ou volta do segurado ao mercado de trabalho após 
Da mesma forma, na esfera internacional, também encontramos diversas decisões judiciais, no sentido de limitar direitos humanos, como se observa, também exemplificativamente, em alguns julgados da Corte Europeia de Direitos Humanos, como S.A.S v. France de $2004^{35}$, ao considerar a lei francesa que vedava "dans l'espace public, porter une tenue destinée à dissimuler son visage", compatível com Convenção Europeia de Direitos Humanos.

Também em Da Conceição Mateus v. Portugal e Santos Januário v. Portugal de 2013³, a Corte Europeia de Direitos Humanos afirmou que haveria uma ampla margem de apreciação ao Estado, em medidas de política econômica ou social, o que permitiria a suspensão total ou parcial de pagamento de subsídios de férias e de Natal para servidores públicos e pensionistas.

Já a Corte Internacional de Justiça (CIJ) em Germany v. Italy: Greece intervening (Ferrini and Distomo case) de $2008^{37}$, e, da mesma forma, a Corte Europeia de Direitos Humanos em Kalogeropoulou and Others v. Greece and Germany de $2002^{38}$, entenderam pela aplicação da regra de imunidade do Estado, mesmo em

concessão do benefício da aposentadoria. Assim, no âmbito do Regime Geral de Previdência Social (RGPS), somente lei pode criar benefícios e vantagens previdenciárias, não havendo, por ora, previsão legal do direito à desaposentação, sendo constitucional a regra do artigo 18, parágrafo 2º da Lei 8.213/1991. Recursos Extraordinários 381367, 661256 e 827833. Disponível em: <http://www.stf.jus.br/portal/cms/verNoticiaDetalhe.asp?idConteudo=328199>. Acesso em: 4 dez. 2016.

${ }^{35} \mathrm{O}$ caso S.A.S v. France, envolvia uma francesa muçulmana, de origem paquistanesa, que questionava a Lei n. 2010-1192 de 11 de Outubro de 2010 (em vigor desde 11 de abril de 2011), que vedava "dans l'espace public, porter une tenue destinée à dissimuler son visage", sob o argumento de violação ao direito à privacidade e à liberdade de religião, expressão e consciência. A CEDH em 2014, entendeu que a proibição não violaria a Convenção Europeia de Direitos Humanos, visto que a vedação normativa, se dirige ao uso em espaço público de roupa ou elemento do vestuário — com ou sem conotação religiosa — que vise esconder o rosto. Além disso, em uma sociedade democrática e pluralista, a possibilidade de "vivre ensemble", se opõe aos vestuários, inclusive o véu, que venham a esconder o rosto. Caso S.A.S v. France. Disponível em: <http://hudoc.echr.coe.int/eng?i=001-145466>. Acesso em: 13 mar. 2016.

${ }^{36}$ Os casos Da Conceição Mateus v. Portugal e Santos Januário v. Portugal julgados pela Corte Europeia de Direitos Humanos, se originaram da decisão do Tribunal Constitucional português no Acórdão 353/2012, que modulou os efeitos da declaração de inconstitucionalidade da Lei 64-B/2011 (Orçamento do Estado para 2012) - que previu a suspensão total ou parcial de pagamento de subsídios de férias e de Natal para servidores públicos e pensionistas — determinando que os efeitos da declaração da inconstitucionalidade não se aplicariam ao ano de 2012, o que gerou, ainda que parcialmente, prejuízo a diversos servidores e pensionistas. A Corte Europeia de Direitos Humanos, ao examinar as alegações, com base no artigo $1^{\circ}$ do Protocolo no 1 da Convenção Europeia de Direitos Humanos (direito de propriedade), afirmou que haveria uma ampla margem de apreciação ao Estado, em medidas de política econômica ou social. Segundo a Corte, as autoridades nacionais estão, em princípio, em melhores condições que o juiz internacional para apreciar o que é do interesse público, por razões sociais ou econômicas, conforme inclusive já decidido pela $\mathrm{CEDH}$ no caso Koufaki and Adedy v. Greece. Contudo, a margem de apreciação pelos Estados nesses domínios é ampla, mas não é ilimitada, uma vez que é preciso analisar se o encargo é ou não desproporcionado e excessivo. No caso, a CEDH entendeu que o legislador se manteve dentro dos limites da sua margem de apreciação, concluindo que não houve encargo desproporcional e excessivo. Casos Da Conceição Mateus v. Portugal e Santos Januário v. Portugal. Disponível em: <http://hudoc.echr.coe.int/eng\#\{"itemid":["001-128106"]\}>. Acesso em: 4 dez. 2016.

37 Caso Germany v. Italy: Greece intervening (Ferrini and Distomo case). Disponível em: <http://www.icjcij.org/docket/files/143/16869.pdf>. Acesso em: 26 jun. 2015.

${ }^{38} \mathrm{O}$ caso Kalogeropoulou and Others v. Greece and Germany, foi levado à CEDH por familiares das vítimas do massacre de Distomo, ocorrido em território grego durante a Segunda Guerra Mundial, com fundamento no artigo 6º da Convenção Europeia de Direitos Humanos e no artigo $1^{\circ}$ do Protocolo n. 1 da Convenção Europeia de Direitos Humanos. A CEDH declarou a demanda inadmissível, sob a premissa de que o direito de acesso ao tribunal, pode ser sujeito a certas limitações, especialmente, na regra de imunidade do Estado. Caso Kalogeropoulou and Others v. Greece and Germany. Disponível em: <http://hudoc.echr.coe.int/eng?i=001-23539>. Acesso em: 13 mar. 2016. 
demandas que envolvam violações aos direitos humanos perpetrados durante a Segunda Guerra Mundial.

Logo, pode-se afirmar que, há a necessidade de se discutir o papel desempenhado pela jurisdição constitucional e de direitos humanos na tutela de direitos, especialmente porque, em sociedades complexas e em condições de pluralismo, o potencial de capacidade deliberativa, sem interferência de tecnicalidades jurídicas que tendem a empobrecer o debate do direito frente à política e à moral, está mais próximo dos processos deliberativos que ocorrem na sociedade e em vários outros fatores relacionados ${ }^{39}$.

Assim, em uma sociedade pluralista, marcada por uma multiplicidade de concepções de vida, a legitimidade das cortes depende de que o procedimento decisório envolva a devida reflexão de visões que possam ser compartilhadas, com base em um acordo racional, bem-informado e voluntário ${ }^{40}$, na projeção conceitual de um sistema que permita que as decisões judiciais sejam desenvolvidas de forma coerente ${ }^{41}$ com outras instituições, a partir de uma visão de previsibilidade e equidade ${ }^{42,43}$.

Ademais, nas sociedades contemporâneas, marcadas pela diversidade de doutrinas religiosas, filosóficas e morais ${ }^{44}$, pessoas com cosmovisões bastante heterogêneas convivem em um mesmo telos social ${ }^{45}$, e, portanto, as controvérsias, não só do sistema de soberanias, mas também da atuação relacional entre os Poderes de Estado e instituições, em suas situações estruturais e atividades de garantia de direitos, deve buscar mecanismos de cooperação, estabelecendo um sistema colaborativo e progressivo das relações sistêmico-dialógica,

\footnotetext{
${ }^{39}$ WALDRON, Jeremy. Law and disagreement. Oxford: Oxford University Press, 1999. p. 111.

${ }^{40}$ WALDRON, Jeremy. O judicial review e as condições da democracia. Tradução de Julia Sichieri Moura. In: BIGONHA, Antônio Carlos Alpino; MOREIRA, Luiz (Orgs.). Limites do controle de constitucionalidade. Rio de Janeiro: Lumen Juris, 2009. Coleção ANPR de direito e democracia.

${ }^{41}$ DWORKIN, Ronald. O império do direito. Tradução de. Jefferson Luiz Camargo. São Paulo: Martins Fontes, 2003, p. 254.

${ }^{42}$ RAWLS, John. O liberalismo político. 2. ed. São Paulo: Ática, 2000, p. 261-305.

${ }^{43} \mathrm{~A}$ justiça como equidade na concepção rawlsiana, envolve dois princípios de justiça: a) o de que toda pessoa tem igual direito a um projeto inteiramente satisfatório de direitos e liberdades básicas iguais para todos (projeto este compatível com os demais), e, nesse projeto, as liberdades políticas deverão ter seu valor equitativo garantido; $\mathrm{e} b$ ) o de que as desigualdades sociais e econômicas, devam estar vinculadas a posições e cargos abertos a todos, em condições de igualdade equitativa de oportunidades, e devem representar o maior benefício possível aos membros menos privilegiados da sociedade. Da junção destes dois princípios (com prioridade do primeiro sobre o segundo), decorrem as instituições básicas de uma democracia constitucional, bem como as características e elementos principais de uma concepção liberal de justiça. Logo, uma concepção política de justiça, deve envolver a devida reflexão (equilíbrio reflexivo), das concepçōes dos indivíduos, refletida em todos os níveis de generalidade. Assim, a justiça como equidade, tem sua ideia organizadora em uma sociedade concebida como um sistema equitativo de cooperação social, entre pessoas livres e iguais. Além do que, tem como objetivo uma concepção de justiça que possa ser compartilhada pelos cidadãos, com base em um acordo político racional, bem-informado e voluntário. Logo, a justiça como equidade, parte da ideia de sociedade como um sistema equitativo de cooperação ao longo do tempo, de uma geração até a seguinte, e, da mesma forma, a teoria da justiça como equidade é uma concepção liberal, bem como uma concepção de justiça válida para uma democracia, proporcionando uma base para os princípios constitucionais e para os direitos e liberdades básicas. RAWLS, John. Justiça e democracia. São Paulo: Martins Fontes, 2000, p. 199-241.

${ }^{44}$ RAWLS, op. cit., p. 205-207.

${ }^{45}$ Este cenário se projeta, naturalmente, para o campo da interpretação constitucional, na medida em que na esfera política, ao lidar com temas essenciais, só são admissíveis argumentos independentes de doutrinas religiosas ou metafísicas controvertidas. Ou seja, na discussão pública, os cidadãos devem apresentar argumentos que possam ser racionalmente aceitos pelos seus interlocutores, independentemente das respectivas crenç̧as religiosas ou metafísicas. RAWLS, John. O liberalismo político. 2. ed. São Paulo: Ática, 2000, p. 261-305.
} 
particularmente porque o manejo da jurisprudência constitucional e de direitos humanos, acaba por trabalhar em descompasso com a legitimidade popular e a questão democrática ${ }^{46}$.

$\mathrm{Na}$ verdade, a questão da legitimidade das cortes interferirem nas decisões dos Estados e do déficit democrático dos juízes, é ainda mais grave no cenário da jurisdição de direitos humanos, uma vez que o elemento consensual inerente ao direito internacional, não dá aos tribunais internacionais base democrática ${ }^{47}$, e, portanto, os tribunais supranacionais não possuem responsabilidade perante os cidadãos de cada um dos países que se submetem à jurisdição daquela Corte ${ }^{48}$, afetando, muitas vezes, a autodeterminação dos povos do Estado-parte, a exemplo do que ocorreu no caso Gelman v. Uruguai julgado pela Corte Interamericana de Direitos Humanos em $2011^{49}$, que negou a validade da lei de anistia (ley de caducidad) uruguaia, mesmo que legitimada, mediante a via da participação direta, em duas ocasiões.

Desta feita, o que se observa é que, sem dúvida, na atividade democrática nas sociedades contemporâneas, a integração estável dos Estados, nas suas relações institucionais, deve ser o resultado de um contínuo diálogo ${ }^{50}$, que permita a determinação do equilíbrio apropriado ${ }^{51,52}$, e a proteção de direitos, a partir da percepção de que a tarefa de guarda dos direitos fundamentais e Direitos humanos, sobretudo no contexto de sociedades marcadas por desacordos persistentes a respeito das mais variadas questões, devem ser resolvidas no plano cooperativo ${ }^{53}$.

\footnotetext{
${ }^{46}$ CHILDRESS III, Donald E. Using Comparative Constitutional Law to Resolve Domestic Federal Questions. Duke Law Journal, n. 53, 2003, p. 221.

${ }^{47}$ FISS, Owen. The Autonomy of Law. Yale Journal of International Law, v. 26, 2001, p. 517 e ss..

${ }^{48}$ MARINONI, Luiz Guilherme. Controle de convencionalidade (na perspectiva do direito brasileiro). In: MARINONI, Luiz Guilherme; MAZZUOLI, Valerio de Oliveira (Coord.). Controle de convencionalidade: um panorama latino-americano: Brasil, Argentina, Chile, México, Peru, Uruguai. Brasília: Gazeta Jurídica, 2013, p. 57-86.

${ }^{49}$ No caso, a Comissão Interamericana de Direitos Humanos, com base nos artigos 51 e 61 da Convenção Americana sobre Direitos Humanos, apresentou demanda contra o Uruguai, em relação ao desaparecimento forçado de María Claudia García Iruretagoyena de Gelman, realizado por agentes estatais uruguaios no final de 1976, bem como, à supressão da identidade e nacionalidade de María Macarena Gelman García Iruretagoyena, filha de María Claudia García de Gelman e Marcelo Gelman. Alegou-se denegação de justiça, impunidade, e, em geral, o sofrimento causado aos familiares de María Claudia García de Gelman, como consequeência da falta de investigação dos fatos, julgamento e sanção dos responsáveis em virtude da Lei 15848 (ley de caducidade), promulgada em 1986. Caso Gelman v. Uruguai. Disponível em: <http://www.corteidh.or.cr/ docs/casos/articulos/seriec_221_esp1.pdf>. Acesso em: 13 mar. 2016.

${ }^{50}$ A Suprema Corte do Canadá, atribuiu uma definição muito ambiciosa de diálogo no caso Vriend v. Alberta de 1998, expondo que os tribunais possuem atribuições visando à defesa da Constituição, e é a própria Constituição expressamente que lhes compete tal papel. No entanto, é igualmente importante o respeito mútuo entre esses poderes, para fins de concretização da democracia constitucional. Caso Vriend v. Alberta. Disponível em: 〈http://scc-csclexum.com/scc-csc/scc-csc/en/1607/1/document.do>. Acesso em: 6 fev. 2016.

${ }^{51}$ TREMBLAY, Luc. The legitimacy of judicial review: the limits of dialogue between courts and legislatures. International Journal of Constitutional Law, v. 3, n. 4, 2005, p. 617-648.

${ }^{52}$ LECLAIR, Jean. Réflexions critiques au sujet de la métaphore du dialogue en droit constitutionnel canadien. Revue du Barreau, Numéro Spécial, 2003. Disponível em: <https://papyrus.bib.umontreal.ca/jspui/ handle/1866/2549>. Acesso em: 10 jan. 2016.

${ }_{53}^{53}$ SUNSTEIN, Cass R. Beyond Judicial Minimalism. Harvard Public Law Working Paper, n. 08-40, 2008. Disponível em: <http://ssrn.com/abstract=1274200>. Acesso em: 6 fev. 2016.
} 


\section{O PAPEL ESTABILIZADOR DAS CORTES NAS SOCIEDADES COMPLEXAS}

Este debate travado nas sociedades complexas, da mesma maneira, acaba por problematizar o tradicional comportamento das Cortes, dentro do parâmetro central de cooperação em uma ordem transnacional, de modo a proporcionar maior coesão e estabilidade, no plano jurídico-político, em um sistema cooperativo e progressivo, a partir das relações entre instituições, de uma comunidade dialógica e convergente ${ }^{54}$.

Portanto, no contexto de uma sociedade bem ordenada, marcada pelo desacordo razoável ${ }^{55}$ e pelo pluralismo, apesar de não haver uma concordância sobre a forma de organização, em termos equitativos, de cooperação entre cidadãos, as cortes devem empregar um procedimento que goza de legitimidade e possa ser aceito por aqueles afetados pela decisão ${ }^{56}$, uma vez que existe uma profunda discordância sobre a melhor maneira de se efetivar os valores da liberdade e igualdade na estrutura básica da sociedade ${ }^{57}$.

Ou seja, para que se possa conquistar o apoio de um consenso sobreposto, que abarque doutrinas religiosas, filosóficas e morais, razoáveis e racionais, baseados na razão e na reflexão bem informada e livremente aceita, o exercício desta dinâmica entre as cortes do sistema transnacional, deve ser exercido de acordo com valores essenciais cujos elementos se pode esperar que razoavelmente todos possam aderir ${ }^{58}$.

Desta feita, diante da possibilidade dos tribunais, cujas decisões, em princípio, são incontrastáveis ${ }^{59}$, dar a última palavra sobre questões complexas, há a necessidade de se estabelecer uma dinâmica segura, na adoção de visões devidamente compartilhadas, diretamente relacionada à ideia de razão pública ${ }^{60}$, como uma cultura

\footnotetext{
${ }^{54}$ ROSENFELD, Michel. The Rule of Law and the Legitimacy of Constitutional Democracy. Cardoso Law School, Working Paper Series, n. 36, 2001. Disponível em: <http://papers.ssrn.com/paper.taf?abstract_id=262350>. Acesso em: 6 fev. 2016.

${ }^{55} \mathrm{O}$ desacordo moral razoável é uma característica das sociedades pluralistas contemporâneas, e duas técnicas principais são usadas para compatibilizar o reconhecimento de cosmovisões diferentes: os compromissos dilatórios e os acordos incompletamente teorizados. Os primeiros, consistem em acordos quanto a princípios gerais, diante da persistência do desacordo em relação a normas específicas. Já os segundos, consistem no oposto, acordos quanto a decisões sobre casos concretos, mantendo-se o desacordo quanto aos seus fundamentos mais gerais. RAWLS, Justiça e democracia. São Paulo: Martins Fontes, 2000, p. $206-212$.

${ }^{56}$ Esta visão se aproxima do conceito de justiça procedimental perfeita de Rawls, ou seja, não há critério independente para o resultado correto, em vez disso, existe um procedimento correto ou justo, de modo que o resultado será também correto ou justo, qualquer que seja ele, contando que o procedimento tenha sido corretamente aplicado. RAWLS, op. cit., p. 116-118.

${ }^{57}$ Uma concepção política de justiça para Rawls, se liga à estrutura básica de uma sociedade, englobando as principais instituições políticas, sociais e econômicas de uma sociedade, e a maneira pela qual se combinam, em um sistema unificado de cooperação social de uma geração até a seguinte. RAWLS, op. cit., p. 53-58.

${ }^{58}$ RAWLS, op. cit., p. 45-53.

${ }^{59} \mathrm{Em}$ sentido oposto, quanto à insindicabilidade dos atos do Poder Legislativo pelo Poder Judiciário, a Constituição irlandesa, por exemplo, prevê que a aplicação das suas normas de justiça social deve ser feita exclusivamente pelo Parlamento, e não deve ser conhecida pelas cortes. O artigo 94 da Constituição brasileira de 1937 e o artigo 68 da Constituição brasileira de 1934, também tratavam da impossibilidade de análise pelo Poder Judiciário das questões exclusivamente políticas. BRANDÃO, Rodrigo. Supremacia judicial versus diálogos constitucionais: a quem cabe a última palavra sobre o sentido da Constituição? Rio de Janeiro: Lumen Juris, 2012, p. 106 e 196.

${ }^{60}$ Nas sociedades democráticas contemporâneas marcadas pelo pluralismo, o princípio da razão pública assume um papel importante. Esse princípio deriva da ideia de "razões públicas", que tem origem na filosofia kantiana, mas foi desenvolvida mais
} 
desenvolvida para uma instrumentalização racional de comunicação e interação entre partes livres e iguais, a partir de um ponto de vista equitativo ${ }^{61}$, em que a atividade interpretativa se processa, em grande parte, por meio de um diálogo permanente entre instituições ${ }^{62,63}$, para melhor conformação de cosmovisões distintas.

É necessário, consequentemente, a conciliação entre os valores da razão pública, na realidade prática da estruturação e da atuação institucional, em uma comunidade na qual haja cooperação jurídico-política, e as cortes se tornem responsáveis pela concretização de um novo modelo de proteção de direitos e garantias fundamentais, com a discussão do redimensionamento do papel dos tribunais e da legitimidade da atuação dos juízes.

Esta modificação conceitual reconhece algumas ideias fundamentais, em especial a de que há um novo paradigma regendo o sistema contemporâneo, em que a questão deixa de ser quem deve interpretar, e passa a indicar a necessidade de se buscar uma teoria construída a partir de uma proposta cooperativa pela qual as cortes

recentemente por John Rawls. A ideia da razão pública é a de que, na esfera política, ao lidar com temas essenciais, só são admissíveis argumentos independentes de doutrinas religiosas ou metafísicas controvertidas. No campo privado, esse limite não se aplica, mas na discussão pública, os cidadãos devem apresentar argumentos também públicos, que possam ser racionalmente aceitos pelos seus interlocutores, independentemente das respectivas crenças religiosas ou metafísicas. John Rawls sustenta ainda que o uso da razão pública, para o cidadão, seria um imperativo moral, mas não jurídico. Isso porque, não haveria, sem grave ofensa à liberdade de expressão e de consciência, como obrigar o cidadão a invocar apenas razões públicas ao deliberar sobre temas essenciais no espaço público. Porém, para os magistrados, a imposição de respeito à razão pública incidiria plenamente. A exigência jurídica de respeito à razão pública, também se dirige a todos os poderes estatais. Atos legislativos e administrativos que violassem essa imposição, baseando-se, por exemplo, em motivações de cunho religioso, não teriam validade. Mas essa imposição, é ainda mais severa para o Poder Judiciário. Os juízes não são eleitos, o que torna ainda mais ilegítima a possibilidade de que imponham os seus valores pessoais sobre os jurisdicionados, ou que os invoquem para derrubar decisões tomadas pelos representantes do povo. Ademais, diferentemente dos parlamentares, que não precisam enunciar publicamente as razões que motivam seus votos, os juízes têm sempre que fundamentar as respectivas decisões. Portanto, os magistrados só estão autorizados a fazer uso da razão pública. RAWLS, John, O liberalismo político. 2. ed. São Paulo: Ática, 2000, p. 261-305.

${ }^{61}$ Rawls trabalha aqui a questão da posição original, a partir da concepção tradicional de justiça, que especifica os princípios adequados para realizar a liberdade e a igualdade. Neste sentido, deve-se buscar um ponto de vista a partir do qual, um acordo equitativo entre pessoas livres e iguais, possa ser estabelecido. A posição original com os traços do "véu da ignorância" (veil of ignorance), é este ponto de vista. Por sua vez, a ideia de "véu da ignorância", se liga à ausência de conhecimento da posição social ou a doutrina abrangente das partes. Ou seja, para haver um acordo equitativo entre pessoas livres e iguais, se deve eliminar as vantagens que surgem em função das tendências sociais, históricas e naturais. Logo, a posição original, deve ser considerada um artifício de representação, e todo acordo entre as partes como hipotético e não histórico. Rawls trata da posição original, como um caso de justiça procedimental pura, no sentido de que os princípios de justiça apropriados para especificar os termos equitativos de cooperação social, são aqueles que seriam selecionados como resultado de um processo de deliberação racional (ao contrário de justiça procedimental imperfeita, em que já há um critério já determinado do que é justo). Assim, as partes não seriam obrigadas a aplicar nenhum princípio de justiça delimitado previamente. RAWLS, op. cit., p. 65-72.

${ }^{62}$ É preferível adotar um modelo que não atribua a nenhuma instituição o "direito de errar por último", abrindo-se a permanente possibilidade de correções recíprocas no campo da hermenêutica, com base na ideia de diálogo, em lugar da visão mais tradicional, que concede a última palavra nessa área aos tribunais. SOUZA NETO, Claudio Pereira. SARMENTO, Daniel. Direito constitucional: teoria, história e métodos de trabalho. Belo Horizonte: Fórum, 2012.

${ }^{63}$ A Suprema Corte do Canadá, por exemplo, no caso R. v. Oakes de 1986, estabeleceu um test case que permite, ao menos em tese, a possibilidade de correções recíprocas entre Poderes, no famoso teste Oakes. Por meio do teste Oakes, se permite analisar se são razoáveis, em casos comprovadamente justificados, limitações a direitos e liberdades (limitations clause), em uma sociedade livre e democrática. Esse teste se aplica, quando se pretende demonstrar que a Seção 1 da Canadian Charter of Rights and Freedoms foi violada. Caso R. v. Oakes. Disponível em: < https://scc-csc.lexum.com/scc-csc/scc-csc/en/item/117/index.do>. Acesso em: 6 fev. 2016. 
possam compartilhar fundamentos comuns ao operacionalizar as ordens jurídica e política da realidade democrática ${ }^{64}$.

Sob esse prisma, a criação de uma rede de reciprocidade, arquitetada a partir de um procedimento de decisão coletiva, compatível com as diferentes concepções de uma sociedade pluralista, passa a transformar o discurso dos direitos fundamentais e dos Direitos humanos, de um monólogo judicial, em um rico e mais equilibrado diálogo interinstitucional, que reduz, se não elimina, a tensão entre a proteção judicial dos direitos e a tomada de decisões ${ }^{65,66}$.

Nesse sentido, as cortes devem atuar dialogicamente, buscando alcançar uma deliberação que atenda aos interesses e valores da coletividade, resultados de uma prática discursiva racional na esfera pública ${ }^{67}$, guiada pelos valores e fundamentos da ordem democrática, fundamentada na necessidade de se firmar tanto um equilíbrio entre o Poder Executivo, Poder Judiciário e Poder Legislativo — questionando a possibilidade de predomínio de qualquer dos Poderes constituídos, bem como a tradicional teoria da separação dos poderes ${ }^{68,69}$, como parâmetros

${ }^{64}$ HOGG, Peter; BUSHELL, Allison. The "Charter" dialogue between Courts and Legislatures. Osgood Hall Law Journal, v. 35, n. $1,1997$.

${ }^{65}$ SUNSTEIN, Cass R; VERMEULE, Adrian. Interpretation and institutions. Chicago Public Law and Legal Theory Working Paper Series, n. 28, 2002.

${ }^{66}$ DIXON, Rosalind. Weak-form judicial review and the American excepcionalism. Chicago Law School Public Law and Legal Theory Working Papers Series, n. 348, 2011.

${ }^{67} \mathrm{~A}$ ideia de esfera pública aqui adotada, se liga à concepção Habermasiana da dimensão pública, na qual ocorre a comunicação entre membros de uma comunidade em discursos racionais, reconhecendo-se mutuamente como membros livres e iguais. Para Jürgen Habermas, o Princípio do Discurso, desempenha um papel relevante na ideia de esfera pública, ao delimitar o modo como ocorre esta comunicação não etnocêntrica e reflexiva, através da ação racional, e com o reconhecimento intersubjetivo de posturas na liberdade comunicativa. Assim, para Habermas, o Princípio do Discurso, toma a forma de um Princípio Democrático, para proporcionar uma função legitimadora a este processo de comunicação entre os membros da comunidade, no processo de formação da opinião, na garantia da autonomia privada e na regulação das relações entre cidadãos livremente associados. Por outro lado, para Jürgen Habermas, o Princípio do Discurso, é autônomo em relação ao direito e à moral. Todavia, como as fundamentações pós-tradicionais, exigem a forma jurídica para compensar os déficits da moral, os preceitos morais são absorvidos pela faticidade de produção normativa, que impõe o comportamento conforme a norma, permitindo que a moral irradie sobre todos os âmbitos de ação. Logo, o fenômeno jurídico, é uma estrutura normativa capaz de contemplar uma abertura para os discursos morais, permitindo o uso da racionalidade comunicativa. Assim, a legitimidade é obtida através da legalidade, na medida em que os processos para a produção de normas jurídicas, são racionais no sentido de uma razão prático-moral procedimental. Desta feita, o direito possui abertura para uma moralidade procedimental, porquanto, para ser legítimo, precisa ser juridicamente sensível às pretensões normativas que são racionalizadas no espaço público. Assim, para Habermas, os fundamentos do direito, estão ancorados na atuação deliberativa/discursiva sobre questões políticas ou morais dos cidadãos discutidos na esfera pública. Logo, a prática discursiva, em um procedimento permanente, possibilita a legitimação do direito, impondo a prática de uma razão comunicativa que constrói o Direito, em uma concepção intersubjetiva de valores morais compartilhados e resultantes dos acertos discursivos, firmados entre sujeitos em uma situação ideal de fala. Nesta condição ideal de fala, não está em jogo um status de igualdade, mas um status de liberdade discursiva, quando os indivíduos procuram o consenso em suas diferentes concepções de mundo. Logo, a condição ideal de fala, se resolve na exigência de se permitir a prática discursiva como uma constante procedimental, isto é, a pessoa e o procedimento racional se configuram a partir de uma prática construtiva discursiva, que busca o consenso e a igualdade entre cidadãos livres e iguais dentro da esfera pública. HABERMAS, Jürgen. Direito e democracia: entre facticidade e validade. Tradução de Flávio Beno Siebeneichler. 2.ed. Rio de Janeiro: Tempo Brasileiro, 2003, v. 1, p. 113-168.

${ }^{68} \mathrm{~A}$ tradicional teoria da separação de poderes, pode ser originalmente atribuída a Aristóteles, e, posteriormente, desenvolvida e aperfeiçoada, por Charles de S. de Montesquieu, em seu livro "O espírito das leis". O modelo norte-americano do checks and balances, proposto pelos federalistas, é uma evolução dessa teoria. LEVINSON, Daryl; PILDES, Richard. Separation of parties, not Powers. Harvard Law Review, v. 119, n. 1, 2006. 
únicos à formulação de um Estado Democrático ${ }^{70}$ —, quanto de se ressaltar a importância das cortes transnacionais frente ao diálogo interestatal contemporâneo ${ }^{71}$.

Desse modo, pode-se entender que a partir dessa visão, pautada nos meios juridicamente legítimos de coadjuvação, os mecanismos de cooperação passam a ser exercidos, tendo em conta o reconhecimento de uma nova e justa parceria, em que o diálogo aprofundado, fundado em um espírito de respeito e tolerância ${ }^{72}$, deve ser um fator inerente à atuação das cortes, em uma troca dinâmica e deliberativa ${ }^{73}$, que concretiza a legitimidade estatal.

Como resultado, a legitimidade das decisões judiciais depende de pluralismo e consensualismo, arquitetados a partir de uma cadeia de reconhecimento, na certeza de que o comprometimento de cada componente é a pedra de toque para criação de um diálogo plural que permita a transformação da sociedade ${ }^{74}$.

\footnotetext{
${ }^{69} \mathrm{Na}$ verdade, segundo Levinson e Pildes em Separation of Parties, Not Powers, a separação de poderes conforme imaginada pelos federalistas americanos, através da doutrina do checks and balances, nunca chegou a ser estabelecida da forma rígida como alguns a imaginam. Assim, haveria uma zona de competência mútua, ou seja, todos os poderes possuiriam aptidão institucional para a realização de todas as tarefas pertinentes ao Estado, contudo, cada um deles, por uma lógica de efetividade, teria atribuições preponderantes. Nesse sentido, para Levinson e Pildes, poucas coisas seriam tão anacrônicas quanto à ideia de separação de poderes. Isto porque, as mudanças no agir político-social, exigem uma reformulação nas bases teóricas, de modo a refletir acerca dos valores que realmente representam a estrutura constitucional. Levinson e Pildes, defendem esta ideia após verificar que, o checks and balances, apresenta lacunas que permitem a concentração de poderes em determinados contextos políticos. Eles apontam que a relação estática e equilibrada que impulsionaria o controle, baseado na relação de freios e contrapesos, é uma ficção, inatingível na prática, uma vez que a atividade pública, ao invés de ser realizada pela ótica institucional, é realizada de maneira personificada, traduzindo todas as tensões políticas e relações de interesse que impulsionam a disputa eleitoral, onde estão em pauta o interesse dos diversos grupos, as alianças políticas e as rivalidades. LEVINSON, loc. cit.

${ }^{70}$ Para uma análise histórica do desenvolvimento da separação de poderes, como uma máxima de organização de Estado e como um modelo de governo baseado na ideia madisoniana de controle entre os poderes de Estado, apresentando, sobretudo, a influência do judicial review nestas transformações. BOLONHA, Carlos; RANGEL, Henrique. Separação de Poderes da Europa aos EUA: mutações e o judicial review. Anais do XX Congresso Nacional do Conselho Nacional de Pesquisa e Pós-Graduação em Direito. Florianópolis: Fundação Boiteux, 2011,p. 11132-11155.

${ }^{71}$ SUNSTEIN, Cass R.; VERMEULE, Adrian. Interpretation and institutions. Chicago Public Law and Legal Theory Working Paper Series, n. 28, 2002.

${ }^{72}$ Podemos citar como exemplo o caso Roe v. Wade de 1973, quanto à questão do aborto nos Estados Unidos. A Suprema Corte decidiu que, o direito de interromper a gravidez, estaria protegido pelo direito constitucional à privacidade. Os grupos que se opuseram à decisão, passaram a tentar revertê-la, enquanto os movimentos no sentido contrário, também se mobilizaram para apoiar o precedente. $\mathrm{O}$ embate entre as posições favoráveis e contrárias ao aborto (pro-life v. pro-choice), demonstrou que a decisão da Suprema Corte não encerrou o debate constitucional sobre o aborto naquele país. O Abortion Act de 1967 do Reino Unido, encerra o mesmo debate, sob o prisma do Poder Legislativo, visto que inúmeros setores da sociedade favoráveis e desfavoráveis ao aborto, se manifestaram durante o procedimento legislativo até a aprovação da norma, contudo, o debate permanece aberto. DWORKIN, Ronald. O domínio da vida. Tradução Jefferson Luiz Camargo. São Paulo: Martins Fontes, 2003, p. 41-94, 141-163 e 207-249.

${ }^{73}$ A Constituição de 1934, contemplava a possibilidade do Poder Legislativo invalidar as decisões proferidas pelo Poder Judiciário em sede de controle de constitucionalidade. Da mesma forma, a Propostas de Emenda Constitucional (PEC) 03/2011 e a arquivada Propostas de Emenda Constitucional (PEC) 33/2011, tratam da possibilidade do Poder Legislativo rever decisões tomadas pelo Poder Judiciário. BRANDÃO, op. cit., p. 6, 137 e 261.

${ }^{74}$ Segundo Rodrigo Brandão, contudo, "há casos em que a dinâmica das relações entre Suprema Corte e Parlamento não se pautou por uma conversa deliberativa, mas por uma lógica conflituosa". O autor refere-se às law in your face canadenses, assim compreendidas as leis destinadas a pura e simplesmente reverter a orientação da Suprema Corte por reputá-la errada ou inaceitável. Segundo ainda Brandão "Cite-se, por exemplo, os casos O'Connor e Mills. No primeiro, o Bispo Hubert O'Connor era acusado de estuprar quatro estudantes aborígenes em uma escola dirigida por ele. Em sua defesa, O'Connor solicitou o acesso a registros dos
} 
Logo, é fundamental a construção de um ambiente pautado na cooperação, na deliberação e no diálogo, na busca da uniformidade de interpretação, decisão e atuação das instituições, tendo como alvo o funcionamento da máquina estatal e a produção de um diálogo efetivo, em que os deveres institucionais sejam determinados mais concretamente, por um procedimento que possa ser concebido como legítimo pela sociedade ${ }^{75}$.

Portanto, a atuação judicial deve ter em conta a compreensão da estrutura do Estado, para que se possa alcançar o objetivo último da segurança e estabilidade jurídica $^{76}$, reafirmando a relação dialética e interdependente da atuação das cortes em uma ordem deliberativo-democrática, em que as questões de interpretação jurídica não possam ser adequadamente resolvidas, sem a atenção à necessidade de se reduzir o déficit de legitimidade das autoridades responsáveis pela construção das decisões judiciais, a partir de um diálogo efetivo na sociedade transnacional ${ }^{77}$.

\section{CONCLUSÃO}

Como pode se observar, na sociedade contemporânea, a jurisdição constitucional e de direitos hunaos, aponta a clara realidade de que o Poder Judiciário cada vez mais trabalha em diversos sistemas jurídicos com uma importante função contra-majoritária, o que traz, por consequência, a ideia de que o Poder Judiciário emite a última palavra sobre questões complexas.

Contudo, da mesma maneira, cada vez mais, a decisão sobre questões morais e políticas complexas, é

tratamentos médico e psicológico das vítimas. A Suprema Corte atribuiu aos juízes competentes o dever de sopesar os direitos à ampla defesa do acusado e à privacidade da vítima, para definir se tais informações deveriam, ou não, ser disponibilizadas aos acusados. Todavia, exígua maioria (cinco juízes) afirmou que não se poderia exigir do acusado a comprovação da relevância dos dados antes de ele tomar conhecimento do seu teor, de maneira que a sua não disponibilização à defesa poderia causar a condenação de inocentes. Desta forma, todas as informações disponíveis para a acusação deveriam ser repassadas à defesa, e os dados sob a guarda de terceiros (médicos, psicólogos etc.) também deveriam lhe ser repassados desde que o juiz do caso considerasse que eles poderiam ter alguma utilidade para a defesa. Já a minoria (quatro juízes) se mostrou cética quanto à utilidade dessas informações para a defesa, e, por outro lado, revelou preocupação quanto à abertura do seu sigilo desestimular denúncias de crimes sexuais e perpetuar a vulnerabilidade das mulheres a violências sexuais. Portanto, enquanto a maioria priorizou o direito do acusado à ampla defesa, a minoria deu preeminência ao direito da vítima à privacidade e ao interesse social em punir eficazmente os crimes sexuais. Dois anos após a decisão, o Parlamento reagiu mediante a aprovação de lei destinada a fazer prevalecer a solução acolhida pela minoria da Suprema Corte, precisamente para tornar mais difícil a utilização em juízo das informações em apreço, e, assim, estimular comunicações de crimes sexuais pelas vítimas. Mais do que isso, a lei usava as mesmas palavras do voto minoritário da juíza L'Hereau Dubeau, superando, ponto a ponto, a solução acolhida pela maioria da corte. Portanto, o Parlamento não buscou uma solução intermediária que incorporasse a visão da corte, antes a reputou inaceitável e simplesmente a reverteu. A lei que superara frontalmente o seu precedente foi julgada constitucional pela Suprema Corte em Mills, que baseou a sua decisão na doutrina dos diálogos constitucionais. Com efeito, a Corte afirmou que a interpretação obtida em O'Connor representava judicially created common law, de forma que não consistia na única interpretação possível, antes o Parlamento poderia propor, como de fato propôs, solução distinta. Neste sentido, a Suprema Corte afirmou que não tem um monopólio na proteção e promoção de direitos e liberdades, e o Parlamento também desempenha um papel importante nesse particular e frequentemente é um aliado importante de grupos vulneráveis". BRANDÃO, loc. cit.

${ }^{75}$ SUNSTEIN, Cass R.; VERMEULE, Adrian. Interpretation and institutions. Chicago Public Law and Legal Theory Working Paper Series, n. 28, 2002.

${ }^{76}$ VERMEULE, Adrian. System effects and the constitution. Harvard Law School Paper, n. 642, 2009. 
reservada para um punhado de juízes não eleitos democraticamente. Assim, em sociedades complexas e em condições de pluralismo, marcada por uma multiplicidade de concepções de vida, a legitimidade das decisões judiciais depende de que seja compatível com as diferentes concepções de justiça existentes em uma sociedade. Logo, não é papel do Poder Judiciário a adoção de teses jurídicas que debatem complexas teorias que se embasam em princípios de alta densidade moral, em detrimento de regras jurídicas preexistentes, como se se conferisse ao Poder Judiciário o domínio exclusivo da interpretação jurídica.

Portanto, diante deste quadro, pode-se estatuir que, este modelo termina, ao final, por não acomodar situações de desacordo razoável, ocorridas em sociedades complexas e em situações de pluralismo. Desta feita, se mostra bastante discutível afirmar que este sistema traz efetivos ganhos qualitativos à questão democrática, ou se, na verdade, este debate global caminha para um obscurecimento da amplitude no debate participativo e pluralista.

Sob esta ótica, concebe-se que a legitimidade das decisões depende do grau de diálogo e consenso entre as partes envolvidas, arquitetado através de uma cadeia de reconhecimento e identidade em relação à decisão, a partir da concepção de que o comprometimento de cada componente é a base de sustentação para criação de uma sociedade cooperativa, que realmente permite a transformação dessa mesma sociedade em um verdadeiro projeto democrático.

\title{
DIALOGICAL COUNTERMAJORITARISM AND THE LEGITIMACY OF INSTITUTIONAL EXPECTATIONS: THE STABILIZE ROLE OF COURTS IN COMPLEX SOCIETIES
}

\begin{abstract}
With the globalization and the development of the so-called interdependent and interpenetrating international society, that interacts more and more deeply every day, the judicial power has expanded throughout the world, crafting the idea that belongs to the Judiciary Bench the last word on constitutional and human rights issues. Therefore, the decisions on complex moral and political issues, in which there are thoughtful social differences in regard of the content and form of interpretation this rights, is performed by non-democratically elected judges. Consequently, the judicial supremacy brings impacts to the democratic question, and therefore, to be legitimized, it must be developed coherently with other institutions and Powers. Thus, in complex societies, the emergence of dialogical-argumentative models, ends up to open the perspectives of the debate of the Courts legitimacy, seeking the balance in a democratic system, in presenting an adequate and effective protection of rights, through a redistribution of Powers between the courts and other institutions, ensuring the dialogue among several actors in the legal and political systems, to assure the improvement of the legitimacy and democratic issue.
\end{abstract}

Keywords: constitutional jurisdiction, human rights, dialogical-argumentative analysis, constitutional courts.

\footnotetext{
${ }^{77}$ BICKEL, Alexander. Foreword: the passive virtues. Harvard Law Review, v. 75, 1961, p. 40.
} 


\section{REFERÊNCIAS CONSULTADAS}

ACKERMAN, Bruce. New separation of powers. Harvard Law Review, v. 133, p. 633, 2000. The Rise of World Constitutionalism. Virginia Law Review, v. 83, p. 771-797, 1997.

ALEXY, Robert. Teoria da argumentação jurídica. 2. ed. São Paulo: Landy, 2005.

BARROSO, Luís Roberto. Judicialização, ativismo e legitimidade democrática. Disponível em: <http://www.oab.org.br/ editora/revista/users/revista/1235066670174218181901.pdf>. Acesso em: 13 jan. 2015.

Neoconstitucionalismo e constitucionalização do direito. O triunfo tardio do direito constitucional no Brasil. In: SAMPAIO, José Adércio Leite (Org.). Constituição e crise política. Belo Horizonte: Del Rey, 2006, p. $97-148$.

BATEUP, Christine. Reassessing the dialogic possibilities of weak-form bills of rights. 2008. Disponível em: $<$ http://works.bepress.com/cgi/viewcontent.cgi?article=1000\&context=christine_bateup $>$. Acesso em: 25 jan. 2013.

BICKEL, Alexander. Foreword: the passive virtues. Harvard Law Review, v. 75, 1961, p. 40.

The least dangerous branch: the Supreme Court at the bar of politics.

BOLONHA, Carlos; RANGEL, Henrique. Separação de Poderes da Europa aos EUA: mutações e o judicial review. Anais do XX Congresso Nacional do Conselho Nacional de Pesquisa e Pós-Graduação em Direito. Florianópolis: Fundação Boiteux, 2011.p. 11132-11155.

BRANDÃO, Rodrigo. Supremacia judicial versus diálogos constitucionais: a quem cabe a última palavra sobre o sentido da Constituição? Rio de Janeiro: Lumen Juris, 2012.

CANON, Bradley C. Defining the Dimensions of Judicial Activism. Judicature, v. 66, n. 6, 1983, p. 236-247.

CHILDRESS III, Donald E. Using Comparative Constitutional Law to Resolve Domestic Federal Questions. Duke Law Journal, n. 53, 2003, p. 221.

DIXON, Rosalind. Designing constitutional dialogue: bills of rights \& the new commonwealth constitutionalism. 2008. 381 f. Dissertation (Doctor of Juridical Science) — Harvard University, Cambridge, 2008.

Weak-form judicial review and the American excepcionalism. Chicago Law School Public Law and Legal Theory Working Papers Series, n. 348, 2011.

DWORKIN, Ronald. Constitutionalism and democracy. European Journal of Philosophy, p. 2-11, 1995.

O direito da liberdade: a leitura moral da Constituição norte-americana. São Paulo: WMF Martins Fontes, 2006, p. 247.

O domínio da vida. Tradução Jefferson Luiz Camargo. São Paulo: Martins Fontes, 2003, p. 41-94, 141 163 e 207-249.

O império do direito. Tradução de. Jefferson Luiz Camargo. São Paulo: Martins Fontes, 2003, p. 254.

The court's embarrassingly bad decisions. New York Review of Books, 2011.

ERICSON, David F. The Nullification Crisis, American Republicanism, and the Force Bill Debate. The Journal of Southern History, v. 61, n. 2, 1995, p. 249-270. 
FEREJOHN, John; PASQUINO, Pasquale. Constitutional adjudication: lessons from Europe, University of Texas Law Review, v. 82, 2004, p. 1671-1704.

FIORAVANTI, Maurizio. Constitución: De la antiguedad a nuestros dias. Tradução Manuel Martinez Neira. Madrid: Trotta, 2001, p. 146.

FISS, Owen. The Autonomy of Law. Yale Journal of International Law, v. 26, 2001, p. 517 e ss.

GARGARELLA, Roberto. La justicia frente al gobierno (sobre el carácter contramayoritario del poder judicial). Barcelona: Ariel, 1996, p. 33 e ss.

La revisión judicial y la difícil relación democracia-derechos. In: ACKERMAN et al. Fundamentos y alcance del controle judicial de constitucionalidad. Madrid: Centro de Estudios Constitucionales, 1991.

GINSBURG, Tom. Judicial Review in New Democracies: Constitutional Courts in Asian Cases. New York: Cambridge University Press, 2003.

GINSBURG, Tom; VERSTEEG, Mila. Why do Countries adopt Constitutional Review? Journal of Law, Economics \& Organization, n. 30, 2014.

GRIFFIN, Stephen. American constitutionalism: from the theory to the politics. Princeton University Press, 1999, p. 88-89.

GRIMM, Dieter. Jurisdição constitucional e democracia. Revista de Direito do Estado, v. 1, n. 4, 2006.

HABERMAS, Jürgen. Direito e democracia: entre facticidade e validade. Tradução Flávio Beno Siebeneichler. 2. ed. Rio de Janeiro: Tempo Brasileiro, 2003.v. 1.

HIRSCHL, Ran. The new Constitucionalism and the judicialization of pure politics worldwide. Fordham: Law Review, v. 75, n. 2, 2006.

HOGG, Peter; BUSHELL, Allison. The "Charter" dialogue between Courts and Legislatures. Osgood Hall Law Journal, v. 35, n. 1, 1997.

HOSEN, Nadirsyah. Promoting democracy and finding the right direction: a review of major constitutional developments in Indonesia. In: CHEN, Albert H. Y. (Ed.). Constitutionalism in Asia in the Early Twenty-First Century. Cambridge: Cambridge University Press, 2014. p. 322-342.

HUSCROFT, Grant. Constitutionalism from the Top Down. Osgood Hall Law Journal, v. 91, 2007.

JUMA, Laurence. Ethnic Politics and the Constitutional Review Process in Kenya. Tulsa Journal of Comparative and International Law, v. 9, p. 471-532, 2001.

KANT, Immanuel. Fundamentação da metafísica dos costumes. Tradução Paulo Quintela. Lisboa: Edições 70, 2007.

KELSEN, Hans. A jurisdição constitucional. 3. ed. São Paulo: Martins Fontes, 2013.

KERSCH, Ken I. The New Legal Transnalionalism, the Globalized Judiciary and the Rule of Law. Washington University Global Studies Law Review, n. 4, 2005, p. 345. 
KOMÁREK, Jan. The Place of Constitutional Courts in the EU. European Constitutional Law Review, v. 9, p. 420-450, 2013.

KOVACS, Andras; VARJU, Marton. Hungary: The Europeanization of judicial review. European Public Law, v. 20, n. 2, p. 195-226, 2014.

KRAMER, Larry D. The people themselves: popular constitutionalism and judicial review. Oxford University Press: Oxford, 2004

The Supreme Court, 2000 Term Foreword: We the Court. Harvard Law Review, 115, 2001.

LECLAIR, Jean. Réflexions critiques au sujet de la métaphore du dialogue en droit constitutionnel canadien. Revue du Barreau, Numéro Spécial, 2003. Disponível em: <https://papyrus.bib.umontreal.ca/jspui/handle/1866/2549>. Acesso em: 10 jan. 2013.

LEVINSON, Daryl; PILDES, Richard. Separation of parties, not Powers. Harvard Law Review, v. 119, n. 1, 2006.

MARINONI, Luiz Guilherme. Controle de convencionalidade (na perspectiva do direito brasileiro). In: MARINONI, Luiz Guilherme; MAZZUOLI, Valerio de Oliveira (Coord.). Controle de convencionalidade: um panorama latino-americano: Brasil, Argentina, Chile, México, Peru, Uruguai. Brasília: Gazeta Jurídica, 2013, p. 5786.

MARTINS DE ARAUJO, Luis Claudio. A jurisdição constitucional no sistema da commonwealth: a conformação de uma nova alternativa institucional à supremacia judicial. Revista Jurídica Luso Brasileira, v. 4, p. 853-877, 2015 .

Supremacia ou diálogos judiciais? O desenvolvimento de uma jurisdição constitucional verdadeiramente democrática a partir da leitura institucional. Revista do Instituto do Direito Brasileiro, v. 1, p. 1-46, 2014.

MENDES, Conrado Hübner. Constitutional Courts and Deliberative Democracy. Oxford: Oxford University Press, 2013.v. 1.272 p.

MOREIRA, Eduardo Ribeiro. Argumentação jurídica e discurso constitucional. Revista Brasileira de Estudos Constitucionais, v. 11, p. 137-167, 2009.

Conselhos constitucionais. Revista de Direito Constitucional e Internacional, v. 71, 2011.

Neoconstitucionalismo e teoria da interpretação. Revista Forense, v. 1, p. 89-105, 2008.

Novos usos da argumentação jurídica. In: MOREIRA, Eduardo Ribeiro (Org.). Argumentação e estado constitucional. São Paulo: Ícone, 2012.v. 1, p. 117-163. p. 681-711.

Por um constitucionalismo global. In: Argumentação e estado constitucional. São Paulo: Ícone, 2012. v. 1.

NEGRETTO, Gabriel. Diseño constitucional y separación de poderes en América Latina. Revista Mexicana de Sociología, v. 65, n. 1, p. 41-76, 2003.

NINO, Carlos Santiago. Ética y derechos humanos. Buenos Aires: Astrea, 1989, p. 32 e ss.

La constituición de la democracia deliberativa. Barcelona: Gedisa, 1997.

Los fundamentos del control judicial de constitucionalidade. Cuadernos y debates, fundamentos y alcance del control judicial de constitucionalidad: Ivestigación colectiva del Centro de Estudios Institucionales de Buenos Aires. Madrid: Centro de Estudios Constitucionales, 1991. 
POSNER, Richard. Against the law reviews. Legal Affairs, v. 57, 2004.

Reply: the institutional dimension on statutory and constitutional interpretation. Michigan Law Review, v. 101, p. $952,2003$.

POSNER, Eric A.; SUNSTEIN, Cass R. On learning from others, Stanford Law Review, v. 59, n. 1309, 2007.

POST, Robert; SIEGEL, Reva. The roe rage: democratic constitutionalism and backlash. Harvard Civil RightsCivil Liberties Law Review, v. 42, p. 373, 2007.

RAWLS, John. A theory of justice. Harvard University Press, 1971. Justiça e democracia. São Paulo: Martins Fontes, 2000. O liberalismo político. 2. ed. São Paulo: Ática, 2000.

RISHWORTH, Paul. The Inevitability of Judicial Review under "Interpretive" Bills of Rights: Canada's Legacy to New Zealand and Commonwealth Constitutionalism? Supreme Court Law Review, v. 23, 2004, p. 233-257.

$\mathrm{ROACH}$, Kent. Dialogue or defiance: legislative reversals of Supreme Court decisions in Canada and the United States. International Journal of Constitutional Law, v. 4, n. 2, 2006.

ROSENFELD, Michel. The Rule of Law and the Legitimacy of Constitutional Democracy. Cardoso Law School, Working Paper Series, n. 36, 2001. Disponível em: <http://papers.ssrn.com/paper.taf?abstract_id=262350>. Acesso em: 6 fev. 2016.

RUGGERI, Antonio; SPADARO, Antonino. Lineamenti di giustizia costituzionale. Torino: G. Giappichelli Editore, 1998.

SANTOLINI, Thierry. La question prioritaire de constitutionnalité au regard du droit comparé. Revue Française de Droit Constitutionnel, n. 93, p. 83-105, 2013.

SMITH, Carsten. The Supreme Court in present-day society. In: TSCHUDI-MADSEN, Stephan (Ed.). The Supreme Court of Norway. Oslo: Aschenhoug and Co., 1998.

SOUZA NETO, Claudio Pereira. SARMENTO, Daniel. Direito constitucional: teoria, história e métodos de trabalho. Belo Horizonte: Fórum, 2012.

SUNSTEIN, Cass R. Beyond Judicial Minimalism. Harvard Public Law Working Paper, n. 08-40, 2008. Disponível em: <http://ssrn.com/abstract=1274200>. Acesso em: 6 fev. 2016.

Designing democracy: what Constitutions do. Adelaide Law Review, v. 23, 397, 2002.

SUNSTEIN, Cass R.; VERMEULE, Adrian. Interpretation and institutions. Chicago Public Law and Legal Theory Working Paper Series, n. 28, 2002.

SWEET, Alec Stone. Constitutional Courts. In: ROSENFELD, Michel; SAJO, András (Ed.). The Oxford Handbook of Constitutional Law. Oxford: Oxford University Press, 2013. p. 816-831.

TATE, C. Neal; VALLINDER, Torbjorn. The global expansion of judicial power. New York University, 1997, p. 13.

TREMBLAY, Luc. The legitimacy of judicial review: the limits of dialogue between Courts and Legislatures. International Journal of Constitutional Law, v. 3, n. 4, 2005. 
TUSHNET, Mark. Taking the constitution away from the courts. Princeton University Press, v. 9, n. 6, 1999.

VERMEULE, Adrian. Many-minds arguments in Legal Theory. Journal of Legal Analysis, n. 1, 2009.

Mechanisms of democracy: institutional design writ small. New York: Oxford System effects and the constitution. Harvard Law School Paper, n. 642, 2009.

WALDRON, Jeremy. Law and disagreement. Oxford: Oxford University Press, 1999.p. 111.

O judicial review e as condições da democracia. Tradução Julia Sichieri Moura. In: BIGONHA, Antônio Carlos Alpino; MOREIRA, Luiz (Orgs.). Limites do controle de constitucionalidade. Rio de Janeiro: Lumen Juris, 2009. Coleção ANPR de direito e democracia.

WALDRON, Jeremy. Refining the question about judges moral capacity. International Journal of Constitutional Law, v. 7, n. 1,2009.

The core of the case against judicial review. The Yale Law Journal, n. 115, 2006.

WALZER, Michael. Pluralism and democracy. Paris: Editions Esprit, 1997.

WOLFE, Christopher. The rise of modern judicial review: from constitutional interpretation to judge-made law. Boston: Littlefield Adams Quality Paperbacks, 1994.

ZURN, Christopher F. Deliberative Democracy and the Institutions of Judicial Review. New York: Cambridge University Press, 2007.

Trabalho enviado em 05 de setembro de 2017.

Aceito em 11 de novembro de 2017. 